\title{
Safety Meeting Material
}

National Cancer Institute

\section{Source}

National Cancer Institute. Safety Meeting Material. NCI Thesaurus. Code C115613.

A collection of agendas, presentation materials, and other documents generated for attendees during a safety report meeting. 